International Journal of Current Advanced Research

ISSN: O: 2319-6475, ISSN: P: 2319 - 6505, Impact Factor: SJIF: 5.995

Available Online at www.journalijcar.org

Volume 6; Issue 3; March 2017; Page No. 2750-2751

DOI: http://dx.doi.org/10.24327/ijcar.2017.2751.0097

CASE REPORT

\title{
LINDANE (GAMMA BENZENE HEXACHLORIDE) INGESTION in 1 YEAR OLD CHILD-A CASE REPORT OF POISOINING
}

\author{
Rahul Gandhi., PD Sharma and Jitender
}

Department of Pediatrics, Adesh Medical College and Hospital, Mohri, Shahabad, Kurukshetra. Haryana, India

\begin{tabular}{|c|c|}
\hline A R T I C L E I N F O & A B S T R A C T \\
\hline Article History: & Lindane (gamma-benzene hexachloride) is widely used as a scabicide by general \\
\hline Received $8^{\text {th }}$ December, 2016 & $\begin{array}{l}\text { practitioners and dermatologists.Lindane toxicity has been reported to occur mostly by way } \\
\text { of dermal exposure. Cases of ingestion are rare }\end{array}$ \\
\hline Received in revised form $19^{\text {th }}$ January, 2017 & We present a case of a 1 year old boy whose mother had suffered from scabies 1 week ago, \\
\hline Accepted $12^{\text {th }}$ February, 2017 & for which he was prescribed lindane along with other medications by a general practitioner. \\
\hline Published online $28^{\text {th }}$ March, 2017 & $\begin{array}{l}\text { The medication was accidentally ingested by child .After } 2 \text { hours of lindane ingestion the } \\
\text { child began to experience seizures. }\end{array}$ \\
\hline
\end{tabular}

Lindane, gamma benzene hexachloride,

poisoning.

Copyright $\odot 2017$ Rahul Gandhi., PD Sharma and Jitender. This is an open access article distributed under the Creative Commons Attribution License, which permits unrestricted use, distribution, and reproduction in any medium, provided the original work is properly cited.

\section{INTRODUCTION}

$\gamma$-Benzene hexachloride $(\mathrm{GBH})$ or popularly known as gammaxene/Lindane is a commonly used insecticide in rural as well as urban households and belongs to organochlorine compounds. Accidental ingestion is not uncommon among children and toxic manifestations comprise chiefly of central nervous system involvement, hepatorenal failure and death.

\section{CASE REPORT}

A 1 year old female child presented in emergency room with H/o Vomiting and Seizures after accidental ingestion of a Gammabenzene Hexachloride(lindane). The Medication was prescribed to mother for local application for treatment of scabies but was accidentally ingested by the child. (Approx. $15 \mathrm{ml}$ ). Child developed 1 episode of vomiting after 15 minutes followed by altered sensorium within one hour of ingestion of medicine and followed by seizures at 2 hours. Seizures were in form of unrolling of Eyeballs, Stiffening of whole body and retraction of neck. It peristed for 1-2 minutes and subsided of its own.

He was brought in emergency after referral. On Examination in Emergency room the child was in deranged sensorium with GCS 10/15. E2M4V4. Vital signs include heart rate 122/Mt, respiratory rate $24 / \mathrm{mt}$, Temperature afebrile, CRT $<3$, peripheral pulses well palpable.

\section{*Corresponding author: Rahul Gandhi}

Department of Pediatrics, Adesh Medical College and Hospital, Mohri, Shahabad, Kurukshetra. Haryana, India
CNS examination showed increasd tone of both upper and lower limbs, pupils bilateral equal and reacting to light, babinski sign was positive with exaggerated DTRs, per abdominal Examination did not revealed any abnormal findings.

In view of increased tone of of B/L upper and lower Limbs Inj midazolam $0.2 \mathrm{mg} / \mathrm{kg}$ was given followed by inj Phenyton Loading $20 \mathrm{mg} / \mathrm{Kg}$ and maintenance was started. Gastric lavage was done with $100 \mathrm{ml}$ normal Saline .The child was kept under observation in ICU. His Biochemical analysis revealed $\mathrm{Na}+146 \mathrm{meq} / \mathrm{l}$. $\mathrm{K}+4.7 \mathrm{meq} / \mathrm{l}$, calcium $9.2 \mathrm{mg} \%$ TLC-16000/cumm- p46\%, L48\% ,M2\#\%, E2 \%Platelet count 5.2 lacs. During the course of stay the child regained consciousness irritability decreased after $6 \mathrm{Hrs}$ and no seizures were observed during the stay of 3 days. The child was discharged on oral epileptic drugs which were tapered and stopped after 3 months of course.

\section{DISCUSSION}

Gamma Benzene Hexachloride is a potent pesticide which is used to kill mites in agriculture. It is a pesticide of high potency and can get absorbed from Skin, respiratory or oral routes. It is prescribed by general practitioners \& dermatologists under name $1 \%$ lindane for treatment of Scabies. It is a CNS stimulant and various reports of toxicity were reported after cutaneous and oral ingestions in adults and children. Children are of big concern as they have large cutaneous surface area, even single application of Lindane $1 \%$ have been reported to cause toxicity. Oral Ingestions is highly lethal and fatalities have been reported. 
Seizures after single overnight application was reported in a 18 months old by Telch 1982

Daviesin1983 [1] reported 16-year-old mentally retarded boy accidentally ingested approximately $392 \mathrm{~g}$ of $1 \%$ lindane shampoo and recovered. A 2-month-old, 4.5-kg, male infant was found dead in his crib after excessive application of a $1 \%$ lindane lotion.

Kurt etal 1986 reported 4 year old boy with seizure after 1 table spoon of Lindane 3 times in a day. At presentation the child was irritable with intermittent increased tone. He also reported a 8 Year body who developed vomiting after 1 table spoon of $1 \%$ Lindane. Similar reporting in three Siblings with acute toxicity after oral ingestion was reported by Nordt \& Chew 1986. Studes from adult after oral and dermal exposures causing varied manufactures like bradycardia, hypotension, Seizures, Coma and metabolic, rhabdomyolys, myoglobinurea, chf, deaths have been reported (Ravet 1988). A four-month-old infant with severe impetigo who had prolonged daily applications of lindane presented with two seizure episodesin 1991 (Ramchandran). AKS etall 1995 [2]presented three such cases, along with a comparison of cases in the literature with respect to blood level half-lives and correlation with signs of toxicity. Tenenbien 1997, reported 16 year old boy with apnea and status epilepticus after ingestion Similar reporting in three Siblings with acute toxicity after oral ingestion was reported by Nordt \& Chew 2000[3]. A 17-month-old female suffered a single seizure. A 3-year-old male was listless, nauseated, pale, and had decreased responsiveness to verbal and tactile stimulation. A 4-year-old female became nauseated and required bag-valvemask ventilation for hypoventilation. The three patients all recovered without sequela .Cox-2000 [4] reported seizures in 2 year old after use of Lindane for head lice. Bhalla 2004[6] described an infant with reversible neurotoxicity following repeated applications of $1 \%$ lindane for the treatment of scabies. Thami 2006[6] reports of its neurotoxicity, especially among infants and young children. A $7 \mathrm{yr}$ boy fter 3 application of lindane the child began to experience Grand mal seizures, ataxia, weakness, in coordination and severe burning paresthesias(daud etal 2010[7] . Paul etall in 2013 [8] reported Benzene hexachloride poisoning leading to acute hepatorenal decomposition
The purpose of highlighting the study and reporting the case is to restrict use of Lindane $1 \%$ of for treatment of scabies when other Scabicidal agents are avaible. FDA recommends lindane as $2^{\text {nd }}$ line Treatment of scabies in view of potential neuro and systemic toxicity.

\section{CONCLUSION}

1. The Drug has a very meagre margin of safety hence should not be recommended

2. The Bottles should be clearly labeled and kept out of reach from children

3. The EEG abnormalities can present even for weeks hence should be followed before discontinuing Anti epileptics.

\section{Referrences}

1. Davies JE, Dedhia HV, Morgade C, Barquet AMaibach HI Arch Dermatol. 1983 Feb; 119(2):142-4.

2. Acute accidental lindane ingestion in toddlers.Aks SE, Krantz A, Hryhrczuk DO, Wagner S, Mock J.Ann Emerg Med. 1995 Nov;26(5):647-51.

3. Acute lindane poisoning in three children.Nordt SP, Chew G. J Emerg Med. 2000 Jan;18(1):5

4. Seizures caused by concomitant use of lindane and dextroamphetamine in a child with attention deficit hyperactivity disorder. Cox R, Krupnick J, Bush N, Houpt A. J Miss State Med Assoc. 2000 Aug;41(8):690

5. Bhalla $\mathbf{M}^{1}$, Thami GP. Reversible neurotoxicity after an overdose of topical lindane in an infant. Pediatr Dermatol. 2004 Sep-Oct;21(5):597

6. Lindane neurotoxicity in childhoodSingal $\mathrm{A}^{1}$, Thami GP Am J Ther. 2006 May-Jun; 13(3):277-80.

7. Daud $\mathrm{Y}^{1}$, Daud-ur-Rehman, Lindane toxicity in a 7 year old. J Ayub Med Coll Abbottabad. 2010 Oct-Dec; 22(4):223.

8. $\gamma$-Benzene hexachloride poisoning leading to acute hepatorenal decompensation. BMJ Case Rep. 2013; 2013: bcr2013009851.

\section{Please cite this article in press as:}

Rahul Gandhi., PD Sharma and Jitender (2017), Lindane (Gamma Benzene Hexachloride) Ingestion In 1 Year Old

Child-a case report of poisoining, International Journal of Current Advanced Research, 6(3), pp. 2750-2751.

http://dx.doi.org/10.24327/ijcar.2017. 2751.0097 